Наталья Бондаренко

Институт языков и культур им. Льва Толстого Кафедра региональных и международных отношений b_natalia@mail.ru
УДК $050(470)(=163.41)$

https://doi.org/10.18485/slavistika.2019.23.1.23

оригинални научни рад примљено 21.03.2019.

прихваћено за штампу 16.05.2019.

\title{
СЕРБСКИЕ СТРАНИЦЫ В «СЛАВЯНСКОМ ВЕСТНИКЕ» А.А. ХОВАНСКОГО
}

В данной статье дается краткий обзор научных статей по сербскому языку и культуре, представленных в сборнике «Славянский вестник». Редактор и издатель Хованский А.А. (1814-1899) опубликовал материалы по языку, литературе, этнографии, мифологии славянских народов. Благодаря сборнику российский читатель смог познакомиться с богатым культурно-историческим наследием славян.

Ключевые слова: Хованский А.А., «Славянский вестник», сербская культура.

This article provides a brief overview of scientific articles on the Serbian language and culture, presented in the collection "Slavonic Bulletin". The editor and publisher A.A. Khovansky (18141899) published materials on language, literature, ethnography, and mythology of Slavic peoples. Thanks to the collection, Russian readers were able to get acquainted with the rich cultural and historical heritage of the Slavs.

Key words: Khovansky A.A., Slavic Bulletin, Serbian culture.

Идея славянской взаимности, теоретически обоснованная в трактате словацкого поэта и философа Яна Коллара «O literárnej vzájomnosti medzi rozličnými kmeňmi a nárečiami slovanského národa» (в 1837 г. - на немецком, а в 1840 г. - на русском языках), в течение XIX в. была доминирующей в культуре славянских народов (Kollár 1954). Как отмечает чешский ученый Ф. Вольман (F. Wollman) ${ }^{1}$, славянская взаимность подразумевает межславянскую культурную и литературную деятельность в духе концепции Яна Коллара. Данная концепция стала основой для широкого обмена культурными ценностями, взаимного познания и сближения славянских народов.

Размышления словацкого ученого о славянском этнокультурном и литературном единстве (как выражении славянского духа) были восприняты всеми славянами как призыв к действию по популяризации славянских языков и культур. Панславизм Я. Коллара оказал большое влияние на чешских, словацких, южнославянских народов, закрепив образ России как лидера славянства. Открытие кафедр славянских языков в Московском, Санкт-Петербургском, Казанском, Харьковском университетах способствовало пробуждению у русского человека интереса к языку, истории, литературе соплеменников.

В газете «День» Аксакова И.С. была опубликована статья. Гильтебрандта П.А, который с сожалением отмечал, что нас (русских) «более интересует гео-

\footnotetext{
${ }^{1}$ Wollman F. K methodologii srovnávaci slovesnosti slovanská. - Brno.1936. Idem. česky slavismus, jeho minulost a program [B:] Slovanstvi v ceskem národnim životě. - Brno.1947: 224. 
графия Африки, нежели география Сербии или Болгарии». Поэтому нам «следовало бы историю, обычаи, культуру славянских народов изучать параллельно с западной», - констатировал автор. (День 1863: № 37, 38). В статье назвалось имя Хованского А.А. (1814-1899), учителя словесности Михайловского кадетского корпуса в г. Воронеже, редактора научного журнала «Филологические записки».

С 1866 года начинает выходить приложение к «Филологическим запискам» под названием «Славянский вестник». Цель данного приложения - познакомить учителей родного языка и словесности с научными исследованиями по сравнительному языкознанию, мифологии, литературе, этнографии и др. В нем публикуют научные работы Афанасьев А.Н., Буслаев Ф.И., Котляревский А.А., Лавровский П.А., Потебня А.А. и др.

В 2016 году к 150-летию «Славянского вестника» при поддержке Фонда Хованского были переизданы три тома публикаций за 1866-1885гг. (Хованский 2016) В работах Ждан Р., Ковалева Г.Ф., Лазарева А.И. были раскрыты основные направления «вестника» ${ }^{2}$. Польский лингвист P. Туровски (R. Turovsky) отмечал роль А.А. Хованского как исследователя индоевропейского влияния на славянскую культуру. (Turovsky R 2016: 184-191)

В предисловии, обращаясь к читателям, Хованский А.А., напоминал слова Яна Коллара, что не умрет идея о взаимности нравственной, литературной у славян, поскольку существует у них (славян) желание литературного общения. Таким образом, имя Хованского А.А. как популяризатора богатого наследия славян становится известным широкому кругу исследователей.

В данной статье сделан краткий обзор публикаций «Славянского вестника», посвященных сербскому языку и культуре в контексте доминирующей в XIX в. идеи славянской взаимности.

Сборник состоит из 3 томов, которые были изданы в период с 1866 по 1885 гг. За эти годы было опубликовано более 30 научных статей, включающих материалы по народной старине, литературе, очерки об известных деятелях, славянские новости переводы.

Редактор и издатель «Записок» Хованский А.А. полагал, что понять красоту языка можно только в сопоставлении с другими славянскими языками, а также с классическими древностями, народной психологией и другими об-

${ }^{2}$ Ждан Р. Интеллектуальный капитал в фокусе наследия А.А. Хованского [B:] «Pulse» 11 Воронеж: 2014: 16-18; Ковалев Г.Ф. «К 150-летию «Славянского вестника» А.А. Хованского [B:] Славянский вестник. История и перспективы. Материалы международной научно-практической конферении, посвященной 150 -летию сборника «Славянский вестник», издававтической конференции, посвященной 150-летию сборника «Славянский вестник», издававшегося под редакцией А.А. Хованкого - основателя журнала «Филологические записки», Воронеж: Кварта, 2016: 200. Лазарев А.И. «Славянский вестник» и московский славянский [В:] АиФ Черноземье 87, Воронеж: 2016

3 Turovsky R. Сравнительный обзор индоевропейских культурно-цивилизационнонных истоков славянства [В:] Славянский вестник. История и перспективы. Материаль международной научно-практической конференции, посвященной 150-летию сборника «Славянский вестник», издававшегося под редакцией А.А. Хованского - основателя журнала «Филологические записки», Воронеж: Кварта, 2016: 184-191. ластями знаний. Он разделял взгляды профессора Срезневского И.И. (1812 $1880)$, который подчеркивал, что язык великороссов, белорусов, малороссов, червеннорусов (в частности) любопытен для исследования судеб русского языка и его обогащения. Напомним, что во Вступительной лекции в курсе истории и литературы славянских наречий Срезневский И.И. отмечал, что российские славяне находятся в контакте с другими славянами и более нуждаются в знании их языка и обычаев. Иначе «ум народа умрет, как умирает ум того, кто приучается заучивать чужие мысли и чужие фразы, не упражняя своего собственного мышления... знания обшеславянской народности отдаляют нас от уродливых заимствований из чужих языков...» (Срезневский 1893: 22).

В трехтомник включены статьи по истории чешского языка и литературы: «Обзор чешской литературы и языка» (перевод с чеш. Медведева К.Н. и Артемьева И.И.) (Хованский 2016: 49-92), Очерк по библиографии чешской литературы с 1860-1877 гг. (Хованский 2016: 93-121) и др.

В разделе «Народная словесность» есть болгарские сказки из собрания братьев Миладиновых; сербское сказание о Св. Савве (Хованский 2016: Т.1: 142 $150)$. В издании опубликованы: статьи: «О современном состоянии языка и литературы у словаков» из архива Соколова (Хованский 2016: Т.2); «Первое литературное движение у русинов в Галиции со времен австрийского господства в этой стране» Головацкого И.Ф. (Хованский Т.1. 162-191); «Фонетика кашубского языка. Филологические исследования П.А. Стремлера», «Этнографический очерк кашубов». Лавровского П.А. (Хованский 2016: Т.1), статьи по мифологии, обзоры, «Разные славянские известия» и др. Таким образом, перед российским читателем открывалась широкая панорама богатого наследия болгарского, русинского сербского, словацкого, словенского, польского, чешского, хорватского народов.

По количеству публикаций материалы по сербскому языку, фольклору, культуре занимают в сборнике второе место после статей по чешскому языку и литературе. И это вполне объяснимо. Нельзя не согласиться с утверждением известного слависта, составителя двуязычной антологии сербской поэзии XX века Числова И.М., который отмечает, что «сербство - это концентрированное выражение славянской этнической памяти» (Числов 2017: 15). Поскольку стержневой составляющей сербской национальной традиции является стойкость и мужество, жертвенность и «родолюбие».

Сербские страницы в «Славянском вестнике» были представлены следующими публикациями: «Звук А отличительная черта сербского вокализма» Кочубинского А.А., (Хованский Т.ІІ. 1-62) «Народные песни о битве на Косовом поле» публикация Мейера В. на основе статьи немецкого ученого Губада Ф.; «Вук Стефанович Караджич» Каравелова Л. (Хованский Т.1. 1-16), сербское сказание о Св. Савве (Хованский Т.I. 1-16); «Преподавание отечественного языка и литературы в сербских гимназиях» автора, подписавшегося М. К-въ (Хованский 2016: T.II. 124-141), а также обзором нескольких песен из собрания Вука Караджича в статье «Славянская семья по народным песням» (автор Лавренок Д.А.) (Хованский Т.I).

Славистика XXIII/1 (2019) 
Идеей духовной свободы всего славянского мира проникнута каждая страница издания. По мнению Хованского А.А. «...не угасли творческие силы, оригинальный славянский дух, и эти силы таятся в быту, душе, поэтическом слове простого народа, в славянской старине» (Хованский 2016: Т.1. 161). Поэтому первый том «Славянского вестника» открывался статей «Славянская семья по народным песням». Данная публикация является органичным продолжением исследований по фольклору Бодянского О.М. (1808-1877) и Срезневского И.И. (1812-1880).

Известно, что в своей магистерской диссертации Бодянский О.М. «О народной поэзии славянских племен» (1837), предпринял попытку раскрыть связь характера песен с историей народа. Для Срезневского И.И. в «Запорожской старине» важным было показать быт, нравы, подвиги малороссов, народа - воина, который своею храбростью заслужил достойное место в памяти потомков. При этом оба ученых подчеркивали «лирический и драматический характер песен». (Срезневский 1883-1838: 36).

Отметим, что позиция Хованского А.А. полностью совпадала с размышлениями ученых, поскольку и Бодянский О.М. и Срезневский И.И. подчеркивали громадное значение изучения языка и фольклора, в частности, Малороссии для российского славянства как залог взаимопознания двух народов.

Для автора статьи «Славянская семья по народным песням» важным было, «собрав разбросанные по песням светлые и мрачные моменты из жизни, выбрать главный мотив, который явился выразителем славянского духа» (Хованский 2016: Т.1. 161).

Анализируя песни малороссов, великороссов, сербов он приходит к выводу, что главное для славянина - это любовь к родной земле, к покинутому дому, к своим родным. В статье анализируются тексты песен «Рабство Стояна Янковича» (из сб. Вука Караджича III № 25), «Якшичи испытывают жен» и др. Автор приходит к выводу, что сербская жизнь благоприятствовала развитию братской любви, а потому для сербских песен характерны «побратимство и посестринство» - замечательное явление среди славян (Хованский 2016: Т.1. 40) Интересны сопоставления славянских песен с кельтскими. Как подчеркивает автор, в кельтских песнях молодежь проводит пору юности в увеселениях, боится семейной жизни. Для славян же характерна замечательная сила «привязанности к семье». Если же славянин оказывается вне семейного круга, который он покинул добровольно, то часто встречается с «горем-злочастием», которое преследует его неотступно. В отличие от кельтов, по мнению автора, славянин равнодушно расстается с молодостью, поскольку пора молодости до брака это только весна любви, настоящая любовь крепнет только после брака. Жизнь славянина - в семье, в ней дышит сила чувства - признак светлых человеческих устремлений славян, - таков вывод автора. (Хованский 2016: Т.1. 28).

Как отмечалось выше, сербский народ является носителем стойкости, силь духа, глубокой непоколебимой веры и жертвенности. Св. Николай Сербский (Велимирович) подчеркивал, что сербскому народу свойственно «мученичество коллективное... Св. Савва молил Бога о том, чтобы весь сербский народ вошел через мученичество в Царство Небесное (греки-логика, русские-лирика, сербы-эпика)» (Св. Николай Сербский 2014: 138).
Сербские страницы в «Славянском вестнике» А. А. Хованского

Поэтому Хованский А.А. публикует статью «Народные песни о битве на Косовом поле» (автор Мейер В.), написанную на основе статьи Ф. Губада ${ }^{4}$ о народных песнях о битве на Косовом поле. (Хованский. 2016: Т.ІІІ). В ней упоминаются имена дубровницких поэтов Гекторовича (ок. 1532) и Бараковича (ок. 1618), которые записывали югославянские песни; Безсонова, предпринявшего попытку соединить в единый цикл песни о Косовом поле (Хованский 2016: T.III. 166).

Автор подчеркивает, что у славян с древних времен бытовали героические песни. Песни Косовского цикла продолжали эту традицию. Именно к этим песням обращались сербы в те времена, когда «...все силы народа устремились к освобождению. Из них молодежь черпала силу к новому бою против врага, а когда смолкли выстрелы, народ утешался древними песнями: с блестящими глазами слушали мальчики, с сомкнутым кулаком слушали юноши пение про героев, храбро шедших на смерть и за отечество, за веру; но скорбь овладевала сердцем каждого мужа, коль скоро раздавалось на гуслях песня о «печальном Косовом поле», и всякий клялся в душе не отдыхать, пока не будет отомщено врагам». (Хованский 2016: T.II. 162). Так «этническая память» о прежнем могуществе и о героизме сербов переходила от поколения к поколению.

Отметим, что влиянию произведений эпических традиций у сербов на русскую литературу 1800-1860 гг. посвящено исследование Осиповой Е.А (Осипова 2016), в котором автор подробно рассматривает предпосылки, повлиявшие на формирование интереса русских литераторов к произведениям сербского героического эпоса.

Для ознакомления широкого круга читателей с южными славянами Хованский А.А. печатает статью «Югославяне», переведенную с чешского Понырко. В ней подробно рассказывается о болгарах, словенцах, хорватах, сербах. По мнению автора, общим признаком южных славян является «древний славянский дух». Славянин «из южных краин - это чистый сын природы, который любит жизнь под широким небом» (Хованский 2016: Т.1. 259). В статье содержится этнографические, исторические сведения о сербах, отмечается «богатая родственная терминология», отражающая тесные связи между братом и сестрой. (Хованский 2016: Т.І. 264).

C XII века начались духовные связи России и Сербии: со встречи Растко с русским паломником, под влиянием которого юный Неманич оказался в монастыре св. Пантелеймона. Поэтому в разделе «Народная словесность» было опубликовано Сказание о Св. Савве. Такая форма повествования позволяла передать в доступной форме для читателя основные христианские добродетели сербского святого. В нем рассказывалось о том, как благодаря терпению, смирению Святого Саввы его путник победил в себе «дурные привычки» обжорство и ложь.

О Вуке Караджиче написал Каравелов Л. Его статья «Вук Стефанович Караджич», посвящена Константину Миладинову (Хованский 2016: Т.1. 134). Автор подчеркивает, что с именем Вука связаны, в первую очередь, возрож-

${ }^{4}$ Magazin für die Literatur des Auslandes № 4-5. 
дение сербской письменности, собирание, издание и популяризация богатого фольклорного наследия сербов. Любен Каравелов подробно рассказывает о жизненном пути Вука, его литературной деятельности, знакомстве с известными учеными: Копитаром Е., Срезневским И.И., Погодиным М.П., Востоковым А.Х., Гете И.В. и др., дает подробный библиографический список произведений Караджича

Среди работ по лингвистике отметим научную публикацию Кочубинского А.А. «О звуке А как черте сербского вокализма», которая является изложением основных положений монографии Вартослава Ягича. Автор, отмечая заслуги лингвиста, указывает на вокализм как главную причину различия в славянских языках (Хованский 2016: T.II. 8). По мнению автора (В. Ягича), русский язык в течение самостоятельной жизни развил полногласие, в сербском - вокализация слов произошла при помощи звука «а» («отьцъ - отецъ - отац»). Обращается внимание на позиции «древнейшего «А», который встречается во всех славянских языках, и «секундарного «А», характерного для сербского языка; подробно анализируются позиции «секундарного «а» в середине, конце слова. Для Хованского А.А. - автора методики «живого слова» - были важны выводы, сделанные В. Ягичем: они давали возможность российским словесникам увидеть особенности истории развития сербского и русского языков

Для редактора и издателя Хованского А.А. особый интерес представлял опыт преподавания родных языков у других славянских народов. Он справедливо считал, что такой опыт будет полезен не только преподавателям гимназий, но и профессорам университетов. Поэтому он публикует заметку о «Преподавании отечественного языка и литературы в сербских гимназиях» (из отчета о заграничной командировке) (Хованский 2016: Т.II. 124).

Автор, М. К - въ, считает систему образования сербской школы «от высшей до народной» неудовлетворительной: на его взгляд, в них отсутствуют практические упражнения, преподавание ведется по разным учебникам, в школах изучается много предметов. «Школы построены на подражательности», - делает вывод автор. (Хованский 2016: T.II. 125). Он положительно оценивает программу для гимназий, утвержденную кн. Милошем. В содержание программы были включены такие дисциплины, как: история Сербии, история славян, изучался древнегреческий язык и др. Однако в 1844 году были внесены изменения, что привело к расширению предметных областей: древнегреческий был заменен латынью, при этом изучались греческая и римская мифология, славянские древности, история России, Польши, Греции, география России и Греции тем самым, как отмечает автор, ученики не «отрывались от славянской почвы» (Хованский 2016: Т. II. 126)

После 1863 года в программах гимназий и университетов («Великая школа») наблюдалась общая негативная тенденция - сокращение часов на обучение родному языку и увеличение часов на изучение французского языка.

Отметим актуальность публикации, сделанной в XIX веке. К сожалению, проблема о соотношении часов на изучение родного и иностранного языков так и осталась на том же уровне (увеличении часов на изучение иностранных языков и сокрашение часов на родной язык). Бесспорно, это негативно влияет на молодое поколение, искусственно отрывая его от родной почвы. Публикация в сборнике. Хованского А.А. интересна тем, что позволяет читателю задуматься над вопросами обучения родному языку в школах.

Таким образом, публикации в «Славянском вестнике» Хованского А.А., посвященные сербскому языку, фольклору давали возможность русскому читателю не только познакомиться с глубинными основами сербского народа, но и ощутить духовную связь с ним.

В завершении следует подчеркнуть, что сборник Хованского А.А. «Славянский вестник» явился продолжением традиции чешских и словацких ученых Йозефа Юнгмана, утверждавшего, что язык и литература - это целостная система ценностей, направленных на всестороннее развитие нации; Франтишека Палацкого, создавшего научную базу исторического сознания как части патриотической идеологии; Йозефа Добровского, автора трудов в области сравнительного языкознания, Павла Йозефа Шафарика, основоположника направления по изучению славянских древностей, Яна Коллара, теория славянской взаимности которого на многие годы обусловила идеи взаимовлияния и популяризации славянских литератур, Людевита Штура и многих других.

«Славянский вестник» Алексея Андреевича Хованского явился тем изданием, в котором российский читатель смог не только обогатить свои представления о славянских народах, но и ощутить свою меру ответственности за все то, что происходит у славян.

\section{Использованная литература}

Бодянский, О.М. «О народной поэзии славянских племен», СПб: 1837.

Осипова, Е.А. Русская литература 1800-1860 гг. и сербская эпическая традиция. Автореферат дис. на соискание ученой степени кандидата филологических наук. Москва, 2016, 34

Срезневский, И.И. «Запорожская старина». Харьков,1833-1838 гг.

Сревневский, И.И. Вступительная лекция в курсе истории и литературы славянских народов. СПб: 1893.

Св. Николай Сербский «Духовные наставления и притчи». Пер. с серб. И.А. Чароты, Минск: Издательство Дмитрия Харченко, 2014.

Хованский, А.А. «Славянский вестник» Т. І-ІІІ. Воронеж: Фонд Хованского, 2016 Числов, И.М. «Малый народ - удивительное явление» [В:] Научный результат. Социальные и гуманитарные исследования. Т. ІІІ: 2017, 11-17.

Kollár Ján O literárnej vzájomnosti medzi rozličnými kmeňmi a nárečiami slovanského národa Bratislava, SAV, 1954

Turovsky R. Сравнительный обзор индоевропейских культурно-цивилизационных истоков славянства [B:] Славянский вестник. История и перспективы. Материалы международной научно-практической конференции, посвященной 150-летию сборника « Славянский вестник», издававшегося под редакцией А.А Хованкого - основателя журнала «Филологические записки». Воронеж: Кварта, 2016, 184-191.

Славистика XXIII/1 (2019) 


\section{Наталија Бондаренко}

\section{СРПСКЕ СТРАНИЦЕ У „СЛОВЕНСКОМ ЗБОРНИКУ” А. А. ХОВАНСКОГ}

\section{Резиме}

Руска журналистика значајно је допринела ширењу знања о Словенима. У додатку часописа „Филологические записки” („Словенском зборнику”) А. А. Ховански, уредник, издавач и наставник руског језика и књижевности у Вороњежу, објавио је низ чланака у којима су била представљена истраживања из области историје, етнографије, језика и књижевности словенских народа. На тај начин он је наставио традицију чешких научника П. Ј. Шафарика, Ј. Добровског, Ф. Палацког, Ј. Колара у погледу популаризације богатог словенског наслеђа. У чланку је дат кратак преглед публикација о српском језику и култури у зборнику А. А. Хованског „Словенски весник” у контексту идеје словенске узајамности која је била доминантна у XIX веку. Материјали о српском епосу, Сказанија о Светом Сави, есеј о Вуку Караџићу, размишљања о појавама у српском језику, белешке о настави матерњег језика у српским гимназијама откривају руском читаоцу живописне странице из историје, фолклора и књижевности братског српског народа. У „Словенском веснику” српска реч „родољубље” у потпуности је испољена као синоним латинској „патриотизам”. Шта може бити драже истинском Словену него љубав према своме роду, своме народу, својој домовини и својим ближњима?

Кључне речи: А. А. Ховански, „Словенски весник”, српска култура. 